\title{
Training and Development Policy, Corporate Governance, and Firm Performance
}

\author{
Rayenda Kbresna Brabmana, ${ }^{1 "}$ Ritzky Karina Brabmana, ${ }^{2}$ and Theresa Char Fei $\mathrm{Ho}^{3}$ \\ ${ }^{1}$ Faculty of Accountancy, Finance and Business, Universiti Sarawak Malaysia, Malaysia \\ ${ }^{2}$ Faculty of Economy and Business, Universitas Kristen Petra Surabaya, Indonesia \\ ${ }^{3}$ Faculty of Accountancy, Finance and Business, Tunku Abdul Rahman University College, Malaysia
}

\begin{abstract}
This research investigates the role of corporate governance as a moderator between firms' performance and their Training and Development Policy (TDP). Research data were taken from the US, Brazil, Russia, India, China and Indonesia from 2007 to 2013. This research found that the TDP is important for enhancing firm performance. Also, the role of the training and development policy impacted each firm's performance differently, according to the level of corporate governance of that firm. The moderating effect of corporate governance reveals that better governance of a firm may have an influence on its TDP policy, which would lead to better firm performance. Overall, the results are consistent with the conjecture that corporate governance influences the firm's performance and training and development policy, suggesting that the training and development policy's success depends on the corporate governance level of the firm. Hence, this research contributes to two big theories: the knowledge transfer theory and the human capital theory, where the research findings show a confirmation of the two theories application in this research context.
\end{abstract}

Keywords: corporate governance; finance; firm performance; training

JEL classification: M53, P34, P46 


\section{Introduction}

An industry report by the International Labour Organization ILO (2006) indicated that organizations in the United States spent a total of $\$ 55.8$ billion on their Training and Development Policies (hereafter TDP). The net direct training expenditure averaged USD 458 per employee and 1.3 percent of the total gross wages and salaries. This number had increased substantially with the compounded growth rate being around 5 percent in 2010, since 1996. Although training is only one way for employee learning to occur, the investment made in training requires an analysis of the evidence to examine if training pays off in organizational effectiveness. However, there is skepticism about the link between training and the results criteria. Training is often criticised for being faddish, too expensive, not transferring to the job, and not improving the bottom line (Bowers 2017; Caudron 2002; Kraiger et al. 2004; Wright and Geroy 2001).

However, several scholars argued that the knowledge and skills of an organization's workforce are significantly important to firm performance, competitiveness, and innovation (Dukhan et al. 2017; Madarisa et al. 2017). According to Kraiger (2003), successful organizations are thought to invest more in training and development than other organizations, where these training and development programmes will lead to improvements in the organizational performance and results (Dolezalek 2005; Salas and Cannon-Bowers 2001).

Further, the TDP performance topics focus only on the costs and benefits of TDP to firm performance without taking into consideration the corporate governance factors. It is important to examine TDP through the agency cost perspective by taking corporate governance as an important factor. Studies done by de Kok et al. (2003), Bunch (2007), and Deng et al. (2012) emphasised that the success of any training and development would depend on the governance of the firm. In other words, the ownership concentration, firm's size, and board structure play important roles in determining the success of the TDP, which is in line with the alignment theorem. Moreover, most of the research conducted in this area only evaluates TDP using reaction criteria (Alliger et al. 1997; Kraiger 2003; Kraiger et al. 2004), and surveys (Nguyen et al. 2011; Ganotakis 2012). Hence this research aims to bridge the research gap in this area.

Nevertheless, the research into the effects of training on performance remains debatable, especially at the organizational level of analysis (Tharenou et al. 2007). Prior researchers such as Hsu and Wang (2010) Subramanian and Youndt (2005) found that human resources have an impact on organizational performance, as the core of an organization. Thus, it is pertinent for an organization to ensure that all the key success factors of TDP must not be taken lightly. This study aims to investigate the association between TDP and firm performance by using samples taken from the US and the leading emerging countries such as Brazil, Russia, India, China, and Indonesia from 2007 to 2013. This study further investigates the relationship by introducing corporate governance into the estimation model as a moderator, to examine whether the performance of TDP would depend on the firms' good corporate governance.

For robustness reasons, this study takes six countries (Brazil, Russia, India, China, Indonesia, and the US) as its sampling frame. There are three reasons to justify this choice of countries. First, much research focuses on 
the developed market context. Adding the leading emerging economies such Brazil, Russia, India, China, and Indonesia may result in a better insight into this research area. To make it more robust, this research added one developed economy, the US, into this research for a better comparison. Second, this research aims to compare the effect of TDP on corporate performance in two different economies of scale. Brazil, Russia, India, China, and Indonesia are the leading developing economies, with a steady pace of capitalization of their stock markets. The GDP and HDI improvements may give different perspectives on the TDP-performance links. Yet, the US, as the representative of the developed markets, might have a different insight on these TDP-performance links. Comparing the results from those countries enriches the generalization of this research. Lastly, each country may have different corporate governance and unique institutional settings. As corporate governance is the moderating variable, adding these six countries may give a better view of the role of governance on the TDP-performance link.

In sum, this study aims to examine the role of corporate governance on the relationship between TDP and firms' corporate performance. This research uses two performance measures: Tobin's $\mathrm{Q}$ and the return on assets. Furthermore, this research has extended the common research design in human resource to a new empirical context and modified the model in terms of some measures and definitions. It also followed previous, established studies by controlling for the firms' characteristics. This research focused on two aspects namely: TDP and corporate governance, and used secondary data for the TDP and the corporate governance index from Asset4, which are all explained in Sec- tion 3. The knowledge theory is used as the base for this research's framework.

This study's contribution is threefold. First, this research enriched the literature by extending the understanding of this research area for the context of both developed countries and developing countries. Second, this research documented the empirical findings of training and developments' effects on corporate values in developed and developing countries. Third, this study further established the fact that corporate governance may play a significant role in determining the performance of a firm in relation to its training and development.

The research paper is organised according to the following sequence. In the next section, the related literature is briefly reviewed. Section 3 describes the data, sample selection criteria, and preliminary analysis. Section 4 shows the findings and discussions. Section 5 presents the conclusion and implications of the research.

\section{Literature review}

Training can be defined as a systematic process of providing employees with certain competencies, such as knowledge, skills and abilities, so that they would be able to carry out their current jobs effectively and efficiently (Lepak and Gowan 2010). As for the term development, it refers to learning experiences that focus more on the long term, for preparing employees for responsibilities in different jobs, usually at the management level (Lepak and Gowan 2010). Both training and development performance are important for organizations because it is impossible for them to grow and compete in this current highly competitive and globalised business environment without them. However, train- 
ing and development is often viewed as a waste of resources, and are implemented just to comply with legal requirements. Training is also perceived by some organizations as a fad without linking the training to measurable results (Tharenou et al. 2007; Caudron 2002; Kraiger et al. 2004).

Recent developments in the literature of strategic management realised the importance of human capital/resources (Kamukama and Sulait 2017; Jardon and Dasilva 2017; Narwal and Yadav 2017; Jardon and Martos 2009). Human capital that possesses skilled and knowledgeable employees through an organization's training and development enables that organization to achieve a competitive advantage over its competitors. Valuable, rare and inimitable resources such as skills and knowledge are considered as resources (Jardon and Dasilva 2017; Narwal and Yadav 2017; Tharenou et al. 2007). Some researchers also equate an organizational learning capability, which in this study is manifested through the training and development of the organization, as a dynamic capability (Ambrosini et al. 2009; Zahra et al. 2006). Dynamic capability can be defined as the capabilities that are geared towards the modification of operational capabilities, such as innovations to the organization's product or processing systems (Zahra et al. 2006). Learning is an important capability that can be a source of sustainable competitive advantage. Investing in developing learning capabilities is crucial in the current competitive environment.

This research uses two theories as the base of the research's framework: the knowledge transfer theory and human capital theory. Knowledge transfer theory means the transferring of knowledge from one organization to other. Using this theory, Hajidimitriou et al. (2012) showed empirical evidence of how well-trained employees would benefit their organization through its knowledge diffusion. Besides that, Deardorff and Djankov (2000) in their study found that knowledge transfer through subcontracting arrangements will indirectly increase a firm's performance when the knowledge transfer theory is properly applied to the organization; it will increase the human capital of the employees and enable the organization to operate efficiently as the human capital of the organization increases. The notion was further supported by Hsiao et al (2017), Tsai (2001) who postulated that when knowledge is being transferred efficiently through an organization, it would be a sustainable competitive advantage for that firm.

Meanwhile, the human capital theory is a theory derived from the classical economics stream. It shows that employees' personal incomes will be different, as they are based on the amount of investment in the human capital of the employees. The investment in employees' human capital means the educational level as well as the training taken by the employees. Marimuthu et al. (2009) stated that human capital is the process of enhancing people by improving their educational level and professionalism, in order to improve their knowledge, skills, values and social assets that may help in improving their organization's performance. This means that when the level of knowledge and ability has been upgraded, this may cause the organization to perform better. Furthermore, Ketchen et al. (2017) and Lepak and Snell (1999) defined human capital as the main component for increasing a business venture's assets and workforce, to increase its efficiency and competitive advantage.

According to Parham and Heling (2015), an employee or worker with human capital will be able to provide a firm with 
important information during the decisionmaking process and investment in the strategic assets. Ahmad et al. (2016) also agreed that the human capital theory means a higher educational level is needed to increase the capability of people, as different levels of education and skills can influence the level of wages. Vomberg et al. (2015) mentioned that there is a positive relationship between human capital and the firm value. This means that when the human capital of the worker or employee is high, the performance of the organization will be better and more efficient.

How training may improve firm performance is debatable. From the perspective of the knowledge theory and resource based view, trained employees should benefit the organization. For instance, Khan et al (2011) showed that training and development have significant effects on organizational performance in Pakistan. They used 100 different samples and revealed that TDP is an important factor for an organization to deliver its vision, mission, and goals and enhance its employees' abilities. Amstrong (2000) argued that TDP is very necessary for an organization, and it must be designed with the needs of the employees in mind. Those organizations which develop a good training design, in accordance with the needs of their employees as well as the organization, always get good results (Boudreau 2006). It seems that the design of the proposed training plays a very vital role in both the employees' and the organization's performance. Badly designed training is nothing but a waste of time and money (Tsaur and Lin 2004).

\section{Methods}

\section{Firm Performance}

Firm performance is calculated by two measurements, namely, the Return on Assets (ROA), and Tobin's Q. In calculating the ROA, this research uses Earnings before Interest, Taxes, and Depreciation (EBITDA) instead of net income as the numerator. The reason is that some industries might have a relative advantage or disadvantage from depreciation and amortization which may lead to biased results. Meanwhile, the denominator of ROA is the book value of assets. The formula is as follows:

$$
R O A=\frac{E B I T D A}{\text { Total Assets }}
$$

This research uses Tobin's Q because it is relatively better at capturing the effectiveness of management (Westerfield et al, 2005). Tobin's Q is the market value of total assets divided by their replacement costs, which can be written as follows:

$$
\text { Tobin's } Q=\frac{\text { MVof Total Assets }}{\operatorname{Re} \text { placementCost }}
$$

\section{Control Variables}

Prior research showed there are four factors that could affect a firm's performance, namely, the firm's size, profitability, growth opportunities, and leverage (Black et al, 2006; Bhagat and Bolton, 2008; Masulis et al. 2012). The basic model is stated as below. 


\section{Value $=f($ Size, Growth Opportunities, Prof- itability, Leverage)}

In measuring a firm's size, this research uses the log of total assets (LTA). Meanwhile, other control variables were developed by following previous research into corporate governance (Black et al. 2006; Bhagat and Bolton 2008; Masulis et al. 2012), where the growth opportunities ratio is capital expenditure divided by sales (CES). The profitability is taken from the ratio of operating income sales ratio (OIS), and ratio of debt to common share equity measures leverage (LEV). Hence, the empirical regression model is shown as Equation 1.

$$
\begin{aligned}
\text { Value }= & \alpha+\beta_{1} \mathrm{LTA}_{i, t}+\beta_{2} \mathrm{LEV}_{i, t}+ \\
& \beta_{3} C E S_{i, t}+\beta_{4} \mathrm{LEV}_{i, t}+\varepsilon_{i, t} .
\end{aligned}
$$

\section{Training and Development Policy (TDP)}

This study uses Asset4 data to retrieve the Training and Development Policy (TDP). The category is a binary dummy variable, which equals 1 for firms which apply a training and development policy.

$$
\begin{aligned}
& \text { Value }=\alpha+\beta_{1} L T A_{i, t}+\beta_{2} L E V_{i, t}+ \\
& \beta_{3} \mathrm{CES}_{i, t}+\beta_{4} \mathrm{LEV}_{i, t}+\beta_{5} \mathrm{TRAIN}_{i, t} \\
& +\varepsilon_{i, t}
\end{aligned}
$$

\section{Corporate Governance}

As the objective of this study is to investigate the role of corporate governance (represented by GOV in the following formulae) in explaining the performance of a training and development policy, this study employed the corporate governance score to represent the level of corporate governance of a firm. The score is calculated from four important dimensions, which are the board's structure, function, compenzation policy, and shareholder rights. Furthermore, it measures a firm's systems and processes, which ensure that its board members and executive act in the best interest of its long term shareholders through its best management practices. Note that the higher the corporate governance score is, the better a firm performs its corporate governance. The data is retrieve from the Asset4 database.

Firstly, this research investigates the role of corporate governance on the firms' performance. The model is as Equation 3.

$$
\begin{aligned}
& \text { Value }=\alpha+\beta_{1} \text { LTA }_{i, t}+\beta_{2} \mathrm{OIS}_{i, t}+ \\
& \beta_{3} C E S_{i, t}+\beta_{4} L_{E V} V_{i, t}+ \\
& \beta_{5} G O V_{i, t}+\varepsilon_{i, t}
\end{aligned}
$$

Then, it proceeds to the investigation of the moderating role of corporate governance on the relationship between TDP and firm performance. The model is as equation 4.

$$
\begin{aligned}
& \text { Value }=\alpha+\beta_{1} \text { LT }_{i, t}+\beta_{2} \mathrm{OIS}_{i, t}+ \\
& \beta_{3} \mathrm{CES}_{i, t}+\beta_{4} \mathrm{LEV}_{i, t}+ \\
& \beta_{5} \operatorname{TR} \mathrm{AIN}^{*} G O V_{i, t} \\
& +\varepsilon_{i, t}
\end{aligned}
$$

\section{Data}

This research retrieved data from the Worldscope and Asset4 databases to collect panel sets of annual financial data for Brazil, Russia, India, China, Indonesia, and the US from 2007 to 2013. This initial sample covers thousands of publicly listed firms. It then filters the listed firms and eliminates firms without complete data to make the balanced 
panel data set. Firms with missing data throughout the six year period were excluded too. At the end, the final data covered around 2,436 firms derived from the 6 countries.

The dummy variable is the measurement of TDP, where 1 is for a firm which implemented TDP and 0 otherwise. In fact, the database provides the TDP in Yes-No codes to classify and distinguish the firms with TDP and without TDP. Meanwhile, corporate governance's score is obtained from Asset 4 , it is calculated based on the 4 main corporate governance functions listed earlier. The higher the score, the better the corporate governance is.

This research runs the models by pooling the data set country by country. This research does not combine it all, or control for the country effect, for two reasons. First, each country has different institutional settings. Pooling the data and adding the country variable as controls causes estimation bias. Second, this research aims to compare the role of TDP on firm performance in each country.

The estimation model is run under a panel regression for each country. The panel data approach allows for assessing changes in the training and development policy and corporate governance over time, albeit not any significant changes in both the levels over time, and thus produces more reliable estimates (see Baltagi 2008). Panel regression controls the correlation between the crosssectional error term and the predictor variables. It also allows the effect of those timeinvariant characteristics to be removed, so it will give a best prediction compared to a cross-sectional analysis or time series analysis (Petersen 2009).

Next, this research ran the full set of diagnostic tests for the panel data following Arrelano and Bond (1991) and Pedroni (2008). It starts with the Wald test for individual effects, the Breusch Pagan LM test for random effects, the Hausman test for fixed effects, and a full set of dynamic settings of for the panel regression (from $\operatorname{AR}(1), \operatorname{AR}(2)$, Sargan test, and Hansen test). Indeed, the Classical Linear Regression Model (CLRM) procedure was estimated preceding those processes. The diagnostic tests show that the model proposed in this research falls into a fixed effect panel regression. Based on -the result of $\operatorname{AR}(1), \operatorname{AR}(2)$, Sargan test, and Hansen test, it does not have endogeneity, even in lag 1. A two-way fixed effect panel

\section{Table 1. Descriptive Statistic Results}

\begin{tabular}{lcccccc}
\hline & US & Brazil & Russia & India & China & Indonesia \\
\hline \multirow{2}{*}{ LTA (1) } & 1.4227 & 0.6249 & 1.0670 & 0.3892 & 1.2377 & 0.4366 \\
& $(6.9845)$ & $(0.4280)$ & $(5.4479)$ & $(0.9571)$ & $(6.1464)$ & $(0.3766)$ \\
OIS (2) & 0.1343 & 0.1188 & 0.1142 & 0.0259 & 0.1142 & 0.0990 \\
& $(0.1339)$ & $(0.1494)$ & $(0.1515)$ & $(0.5063)$ & $(0.1152)$ & $(0.1285)$ \\
CES (3) & 0.1571 & 0.1272 & 0.1273 & 0.1217 & 0.1430 & 0.1575 \\
& $(0.3214)$ & $(0.1687)$ & $(0.2635)$ & $(0.2418)$ & $(0.2957)$ & $(0.1552)$ \\
LEV (4) & 0.0285 & 1.0294 & 0.0239 & 2.3580 & 0.0314 & 1.1323 \\
& $(0.4834)$ & $(2.9599)$ & $(0.4012)$ & $(2.3852)$ & $(0.5801)$ & $(3.5519)$ \\
TOBIN'S Q (5) & 0.2335 & 0.2919 & 0.2569 & 0.3269 & 0.3036 & 0.2802 \\
& $(0.4689)$ & $(0.1449)$ & $(0.1470)$ & $(2.3136)$ & $(0.5627)$ & $(0.1246)$ \\
& & & & & & \\
\hline
\end{tabular}


Table 1. Continued

\begin{tabular}{|c|c|c|c|c|c|c|}
\hline & US & Brazil & Russia & India & China & Indonesia \\
\hline $\mathrm{ROA}(6)$ & $\begin{array}{c}0.1982 \\
(0.3571)\end{array}$ & $\begin{array}{c}0.2378 \\
(0.2152)\end{array}$ & $\begin{array}{c}0.2220 \\
(0.2632)\end{array}$ & $\begin{array}{c}0.2180 \\
(0.8518)\end{array}$ & $\begin{array}{c}0.2676 \\
(0.3352)\end{array}$ & $\begin{array}{c}0.2478 \\
(1.0078)\end{array}$ \\
\hline \multicolumn{7}{|c|}{ Satterthwaite-Welch's t-test } \\
\hline$(1)-(2)$ & $\begin{array}{c}0.0804 \\
(0.7890)\end{array}$ & $\begin{array}{c}0.5949^{* * *} \\
(0.0010)\end{array}$ & $\begin{array}{c}0.8740^{* * *} \\
(0.0000)\end{array}$ & $\begin{array}{c}0.231^{* *} \\
(0.0230)\end{array}$ & $\begin{array}{c}0.7100^{*} \\
(0.0620)\end{array}$ & $\begin{array}{c}0.4176^{\text {*** }} \\
(0.0061)\end{array}$ \\
\hline$(1)-(3)$ & $\begin{array}{c}0.8857^{\text {*** }} \\
(0.0000)\end{array}$ & $\begin{array}{l}0.3844^{* *} \\
(0.0150)\end{array}$ & $\begin{array}{l}0.2986^{* *} \\
(0.0380)\end{array}$ & $\begin{array}{c}0.0716 \\
(0.5080)\end{array}$ & $\begin{array}{c}1.2261^{\text {*** }} \\
0.0000\end{array}$ & $\begin{array}{c}1.2977^{* * *} \\
0.0000\end{array}$ \\
\hline$(1)-(4)$ & $\begin{array}{l}0.0769^{* *} \\
(0.0110)\end{array}$ & $\begin{array}{c}0.0275^{* *} \\
(0.0450)\end{array}$ & $\begin{array}{c}0.1578^{\text {*** }} \\
(0.0080)\end{array}$ & $\begin{array}{c}0.1407^{* *} \\
(0.0103)\end{array}$ & $\begin{array}{c}0.0693^{* *} \\
(0.0135)\end{array}$ & $\begin{array}{c}0.0477^{* *} \\
(0.0358)\end{array}$ \\
\hline$(1)-(5)$ & $\begin{array}{c}0.0334^{* *} \\
(0.0429)\end{array}$ & $\begin{array}{c}0.0590 \\
(0.1660)\end{array}$ & $\begin{array}{l}0.0265^{*} \\
(0.0686)\end{array}$ & $\begin{array}{l}0.0737^{*} \\
(0.0940)\end{array}$ & $\begin{array}{c}0.0501^{* *} \\
(0.0253)\end{array}$ & $\begin{array}{l}0.0208^{*} \\
(0.0575)\end{array}$ \\
\hline$(1)-(6)$ & $\begin{array}{c}1.0579 \\
(0.0545)^{*}\end{array}$ & $\begin{array}{c}0.7686^{*} \\
(0.0776)\end{array}$ & $\begin{array}{c}1.3286^{*} \\
(0.0738)\end{array}$ & $\begin{array}{l}0.2894^{*} \\
(0.0592)\end{array}$ & $\begin{array}{l}(2.3865) \\
(0.2380)\end{array}$ & $\begin{array}{l}(2.0972) \\
(0.2994)\end{array}$ \\
\hline$(2)-(3)$ & $\begin{array}{c}2.4254^{* * *} \\
(0.0030)\end{array}$ & $\begin{array}{l}(4.6514) \\
(0.4240)\end{array}$ & $\begin{array}{c}6.2868^{* *} \\
(0.0160)\end{array}$ & $\begin{array}{c}0.2044^{\text {** }} \\
(0.0400)\end{array}$ & $\begin{array}{l}3.1969 * \\
(0.0520)\end{array}$ & $\begin{array}{c}5.7192^{* * *} \\
(0.0050)\end{array}$ \\
\hline$(2)-(4)$ & $\begin{array}{c}0.0804 \\
(0.7890)\end{array}$ & $\begin{array}{c}0.5949^{* * *} \\
(0.0010)\end{array}$ & $\begin{array}{c}0.8740^{\text {*** }} \\
(0.0000)\end{array}$ & $\begin{array}{c}0.2311^{\text {** }} \\
(0.0230)\end{array}$ & $\begin{array}{c}0.7100^{*} \\
(0.0620)\end{array}$ & $\begin{array}{c}0.4176^{* * *} \\
(0.0061)\end{array}$ \\
\hline$(2)-(5)$ & $\begin{array}{c}0.9034^{* * *} \\
(0.0002)\end{array}$ & $\begin{array}{c}0.3959^{* *} \\
(0.0225)\end{array}$ & $\begin{array}{c}0.3105^{* * *} \\
(0.0002)\end{array}$ & $\begin{array}{c}0.0737 \\
(0.5080)\end{array}$ & $\begin{array}{l}1.2874^{* * *} \\
(0.0030)\end{array}$ & $\begin{array}{l}1.3496^{* * *} \\
(0.0000)\end{array}$ \\
\hline$(2)-(6)$ & $\begin{array}{c}0.0723^{* *} \\
(0.0220)\end{array}$ & $\begin{array}{c}0.0267^{* *} \\
(0.0285)\end{array}$ & $\begin{array}{c}0.1468^{* * *} \\
(0.0050)\end{array}$ & $\begin{array}{c}0.1351^{\text {** }} \\
(0.0104)\end{array}$ & $\begin{array}{c}0.0658^{* *} \\
(0.0194)\end{array}$ & $\begin{array}{c}0.0448^{* * *} \\
(0.0000)\end{array}$ \\
\hline (3)-(4) & $\begin{array}{c}0.0354^{* *} \\
(0.0429)\end{array}$ & $\begin{array}{l}0.0608^{*} \\
(0.0575)\end{array}$ & $\begin{array}{l}0.0270^{*} \\
(0.0904)\end{array}$ & $\begin{array}{l}0.0789 * \\
(0.0528)\end{array}$ & $\begin{array}{c}0.0521^{* *} \\
(0.0400)\end{array}$ & $\begin{array}{c}0.0218^{* *} \\
(0.0133)\end{array}$ \\
\hline$(3)-(5)$ & $\begin{array}{c}1.0674 \\
(0.1012)\end{array}$ & $\begin{array}{l}0.7747^{*} \\
(0.0520)\end{array}$ & $\begin{array}{c}1.3406^{*} \\
(0.0821)\end{array}$ & $\begin{array}{l}0.2923^{*} \\
(0.0738)\end{array}$ & $\begin{array}{c}2.6252^{* * *} \\
(0.0000)\end{array}$ & $\begin{array}{c}2.2650^{* * *} \\
(0.0000)\end{array}$ \\
\hline (3)-(6) & $\begin{array}{c}1.0516 \\
(0.1301)\end{array}$ & $\begin{array}{l}0.7486 * \\
(0.0766)\end{array}$ & $\begin{array}{c}1.3073^{* * *} \\
(0.0000)\end{array}$ & $\begin{array}{l}0.2790^{*} \\
(0.0776)\end{array}$ & $\begin{array}{c}2.2767 \\
(0.4230)\end{array}$ & $\begin{array}{l}1.9798^{* *} \\
(0.0150)\end{array}$ \\
\hline$(4)-(5)$ & $\begin{array}{c}2.6437^{* * *} \\
(0.0000)\end{array}$ & $\begin{array}{c}5.0235 \\
(0.3392)\end{array}$ & $\begin{array}{c}6.7269^{* *} \\
(0.0400)\end{array}$ & $\begin{array}{c}0.2228 \\
(0.1664)\end{array}$ & $\begin{array}{c}3.4527 \\
(0.2664)\end{array}$ & $\begin{array}{c}6.1195^{* *} \\
(0.0381)\end{array}$ \\
\hline$(4)-(6)$ & $\begin{array}{c}2.4375^{\text {*** }} \\
(0.0000)\end{array}$ & $\begin{array}{c}4.6793^{* * *} \\
(0.0000)\end{array}$ & $\begin{array}{c}6.3308^{* *} \\
(0.0170)\end{array}$ & $\begin{array}{c}0.2060 \\
(0.2380)\end{array}$ & $\begin{array}{c}3.2257 \\
(0.2994)\end{array}$ & $\begin{array}{c}6.2911^{* * *} \\
(0.0070)\end{array}$ \\
\hline
\end{tabular}

Note: that for the descriptive statistic, figures are mean value, and figures in the parenthesis are standard deviation; SW $\mathrm{t}$ test refers to Satterthwaite-Welch's $\mathrm{t}$ test and the figures in the parenthesis under SW $\mathrm{t}$ test are $\mathrm{p}$-values. , ,*, and ${ }^{* * *}$ denotes statistical significant at the 1 percent, 5 percent, and 10 percent level, respectively. 
regression is employed to make the model more robust.

\section{Results and Discussion}

\section{Descriptive Results}

Table 1 describes the summary of statistic for this research's sample of 2,346 firms across the six countries (US, Brazil, Russia, India, China, and Indonesia) and seven periods (2007-2013). The mean values were calculated for each variable to facilitate comparison among the variables. These mean values are provided, including their standard deviation values, which are depicted in parenthesis. This research also provides the statistical test for the difference in the mean value for each variable across the six variables. As expected, firms in the US have the best financial ratios among all six countries. Then comes Russia. This reveals that developed countries such the US and Russia (members of the D-8) have relatively better performance as compared to those emerging markets such as Brazil, India, China, and Indonesia.

Even though the panel data does not strongly pre-requisite normality, it reports low values for the standard deviation and good values for the mean, which implies that there is no such type- 1 error in this data. Furthermore, the t-test indicates that there are significant differences among the variables, meaning each value of each variable has a different indicator. This illustrates that each financial ratio has a different financial measure. This is also important as it differentiates the performance measures between Tobin's Q and ROA. The findings in Table 1 imply that there is no such cross-measure from each variable (multicollinearity) and also there is no such autocorrelation.

\section{Baseline Results}

Table 2 presents the panel regression results for the baseline model (Model 1). With short panel data (the number of firms is significantly larger than the number of years), it reports the probability values based on White robust standard errors that control for heteroscedasticity errors, as well as firm clustering, year clustering, and the period effect which will induce the within-firm serial correlation error structure. Basically the coefficient estimated for all the variables is consistent in sign and magnitude across the various specifications, except for the significance level of several control variables in certain countries, due to country characteristics (e.g. developed vs developing or labor-intensive vs technology-intensive). This research starts with the US, which is the largest and most developed market in this sample. As expected, all the four control variables basically contribute positively to the firms' performance and they are statistically significant except for the size (LTA). Meanwhile, the adjusted R2 of the model is 24.43 percent (Tobin's Q model) and 23.84 percent (ROA model) which is the largest compared to the other markets. The baseline model estimation for US shows there is no different conclusion between Tobin's Q model and the ROA model. It then continues to Brazil's results where the adjusted R2 is good enough, 19.75 percent for Tobin's Q model and 18.22 percent for the ROA model. The control variables of Brazil were slightly different from the US results. Only profitability (OIS) and leverage (LEV) contributed significantly to Brazilian firms' performance.

The results of the baseline model for Russia were considerably different. The adjusted R2 values are still good enough, at 14.70 percent for Tobin's Q and 14.38 percent for ROA. However, only one control 
variable contributed significantly to the firms' performance, which is profitability. The rest, such as size, leverage, and growth, failed to influence the performance of the listed firms in Russia. In the Indian context, the adjusted $\mathrm{R} 2$ also indicates the model is good enough in terms of the predictors' variance. The values are 16.61 percent and 18.26 percent for Tobin's Q model and the ROA model, respectively. The control variables contribute positively to the performance. However, similar to the US model's results, it is only size that does not influence the performance significantly. Profitability, growth, and leverage are statistically significant at the 5 percent level for the firms' performance. This is the same conclusion with China and Indonesia. In
China's context, all the control variables except size contributed significantly to the firms' performance. It is noteworthy that those models are good enough where the adjusted R2s are 20.19 percent and 17.83 percent for the Tobin's Q and ROA respectively. In the Indonesian context, where the adjusted R2s are also good enough $(17.11 \%$ for Tobin's Q and 16.93 for ROA), profitability, growth, and leverage have also influenced the performance of the firms significantly, at the 5 percent level. Size, on other hand, fails to have a statistically significant role in the firms' performance. The baseline model results are consistent with previous research, such as that by Black et al (2006) and Masulis et al (2012)

Table 2. Estimates of Baseline Model

\begin{tabular}{|c|c|c|c|c|}
\hline & \multicolumn{2}{|c|}{ US } & \multicolumn{2}{|c|}{ Brazil } \\
\hline & Tobin's Q & ROA & Tobin's Q & ROA \\
\hline \multirow{2}{*}{ INTERCEPT } & $2.1489 * * *$ & $1.9552^{* * *}$ & $1.7234 * * *$ & $1.9562 * * *$ \\
\hline & $(0.0000)$ & $(0.0000)$ & $(0.0000)$ & $(0.0020)$ \\
\hline \multirow{2}{*}{ LTA } & 0.0316 & 0.0023 & 0.0201 & 0.0111 \\
\hline & $(0.8190)$ & $(0.9828)$ & $(0.3941)$ & $(0.5457)$ \\
\hline \multirow{2}{*}{ OIS } & $0.0453 * * *$ & $0.0438^{* *}$ & $0.0675^{* * *}$ & $0.0610 * * *$ \\
\hline & $(0.0008)$ & $(0.0122)$ & $(0.0000)$ & $(0.0002)$ \\
\hline \multirow{2}{*}{ CES } & $0.9317 * * *$ & $0.9046^{* *}$ & 0.1990 & 0.1872 \\
\hline & $(0.0018)$ & $(0.0207)$ & $(0.8434)$ & $(0.7905)$ \\
\hline \multirow{2}{*}{ LEV } & $0.5226 * * *$ & $0.5194 * * *$ & $0.3808^{* * *}$ & $0.4626 * * *$ \\
\hline & $(0.0000)$ & $(0.0020)$ & $(0.0096)$ & $(0.0070)$ \\
\hline \multirow[t]{2}{*}{ Adj R2 } & 0.2443 & 0.2384 & 0.1975 & 0.1822 \\
\hline & \multicolumn{2}{|c|}{ Rusia } & \multicolumn{2}{|c|}{ India } \\
\hline \multirow{2}{*}{ INTERCEPT } & $1.0193^{* * *}$ & $1.0207 * * *$ & $1.2262^{* * *}$ & $1.4048^{* * *}$ \\
\hline & $(0.0000)$ & $(0.0000)$ & $(0.0000)$ & $(0.0000)$ \\
\hline \multirow{2}{*}{ LTA } & 0.0492 & 0.0440 & 0.0248 & 0.0323 \\
\hline & $(0.6303)$ & $(0.6182)$ & $(0.2461)$ & $(0.8832)$ \\
\hline \multirow{2}{*}{ OIS } & $0.0206^{* * *}$ & $0.0201 * * *$ & $0.0294 * * *$ & $0.0207 * *$ \\
\hline & $(0.0001)$ & $(0.0020)$ & $(0.0026)$ & $(0.0404)$ \\
\hline
\end{tabular}


Table 2. Continued

\begin{tabular}{lcccc}
\hline & \multicolumn{2}{c}{ US } & \multicolumn{2}{c}{ Brazil } \\
\cline { 2 - 5 } Cobin's Q & ROA & Tobin's Q & ROA \\
\cline { 2 - 5 } LEV & 0.1136 & 0.1184 & $0.6858^{* * *}$ & $0.6313^{*}$ \\
& $(0.8467)$ & $(0.6171)$ & $(0.0002)$ & $(0.0781)$ \\
Adj R2 & 0.1271 & 0.1367 & $0.3019^{* *}$ & $0.4991^{* * *}$ \\
\hline \multirow{2}{*}{ INTERCEPT } & $(0.2533)$ & $(0.1125)$ & $(0.0323)$ & $(0.0000)$ \\
& 0.1470 & 0.1438 & 0.1661 & 0.1826 \\
LTA & $1.3449^{* * *}$ & $1.0430^{* * *}$ & $1.3272^{* * *}$ & $1.4320^{* * *}$ \\
& $(0.0000)$ & $(0.0000)$ & $(0.0000)$ & $(0.0020)$ \\
OIS & 0.0401 & 0.0202 & 0.0329 & 0.0330 \\
& $(0.6841)$ & $(0.2315)$ & $(0.8294)$ & $(0.4105)$ \\
CES & $0.0430^{* * *}$ & $0.0372^{* *}$ & $0.0575^{* *}$ & $0.0508^{* *}$ \\
& $(0.0025)$ & $(0.0160)$ & $(0.0121)$ & $(0.0246)$ \\
LEV & $0.5745^{* * *}$ & $0.5085^{* *}$ & $0.4479^{* *}$ & $0.4327^{*}$ \\
Adj R2 & $(0.0053)$ & $(0.0276)$ & $(0.0464)$ & $(0.0711)$ \\
\hline
\end{tabular}

The regression is performed using two different measures of performance: Tobin's $Q$ and ROA. The figure stated are the coefficient values, except numbers in parentheses which are $p$-value. The dependent variable is firm performance. The control variables are relative size (RLTA), relative profitability (ROIS), relative growth (RCES), and relative leverage (RLEV). The model is as follow: Value $=\alpha+\beta_{1} L T A_{i, t}+\beta_{2} O I S_{i, t}+\beta_{3} C E S_{i, t}+\beta_{4} L E V_{i, t}+\varepsilon_{i, t}$

\section{The Role of Training and Development}

This research further estimated Model (2) to examine the role of the Training and Development Policy (TDP) on the firms' performance. Table 3 contains the model's results for the performance of TDP from the six countries. Those estimations with two different performance measurements have the estimation of $\mathrm{R} 2$, which range from 12 percent to 28 percent.

The estimation of Model (2) shows that both Tobin's Q and ROA are positively related to TDP. In the context of the US, this research finds the TDP contributed positively to the firms' performance. The coefficient values are 0.5527 and 0.4278 for Tobin's $Q$ and ROA, respectively. TDP is also statistically significant for the firms' performance. This means imposing TDP might help firms in the US to improve their performance, not only based on their accounting performance, such as ROA, but also their market-based performance, such as Tobin's Q. It arrived at the same conclusion for the Brazilian context. TDP contributed positively and significantly to the performance of Brazilian firms. The coefficient values are 0.5314 and 0.4919 for Tobin's Q and ROA. Again, this indicates 
that TDP might improve the firms' performance in Brazil.

This research then looked at the other countries such as Russia, India, China, and Indonesia. The conclusion remains the same; TDP has played an important role in firm performance. In Russia, TDP has a good magnitude of influence on the firms' performance where the coefficients estimated are 0.4497 and 0.4250 for the Tobin's Q model and ROA model, respectively. However, firms in India are not significantly associated with TDP. This is the same conclusion with firms in China. Lastly, firms in Indonesia show the TDP's contribution to the firms' performance is statistically significant, with coefficient values of 0.4026 and 0.4840 for Tobin's Q model and the ROA model, respectively.

Interestingly, the coefficients estimated for the control variables changed their significant role in performance after TDP was introduced into the model, except in the context of the US. This research finds that the estimated coefficients of size, profitability, growth, and leverage has lost its contribution in association with firm performance. For instance, the leverage does not play a significant role on firm performance in Brazil in the research sample. Only profitability has a significant contribution to both Tobin's $Q$ and ROA. This is also the same for Indonesia. The growth and leverage have lost their significant contribution to firm performance, so only profitability plays an important role in Indonesian firms' performance. Interesting findings are found in the context of Russia, India, and China. All the control variables that once made significant contributions to firm performance have turned out to not be significant when TDP was introduced in the model. For example Russia, where the baseline model's results show a significant contribution by profitability. Yet, Table 3 reports profitability is not a significant predictor of firm performance in Russia when TDP is introduced. The same conclusion goes for India and China. Profitability, growth, and leverage contributed significantly to firm performance in those 2 countries. However, after TDP was introduced, there was no control variable that had a significant influence on firm performance. In the context of the US, the role of control variables towards firm performance is a stronghold where all the control variables contribute positively and significantly to firm performance, except for size.

Note that this research finds another interesting result. The coefficients estimated for size and growth in all the countries except for the US have changed their sign; which is inconsistent with the baseline model. The coefficients of LTA (size) and CES (growth) change from positive to negative. This means that TDP may positively contributed to performance, however, the economy of scale such as size, profitability, growth, and leverage have new conclusion.

Overall, the findings supported the hypotheses in this research. The results indicated that there is a significant role for TDP in the firms' performance. This shows that if a good TDP is imposed, the firm will perform much better. This means the findings are consistent with previous research, such as that by Storey (2002), Storey (2004), and Kwon and Rupp (2013), who all found the significant role of training and development on firm performance. However, after introducing the TDP into the model, the control variables produced different results. All the countries except for the US have lost the role of the control variables. Moreover, some countries experienced changes in the coefficients' signs from positive to negative for the firms' performance. 
It is possible, however, that these changes are caused by the cost of the TDP, or good corporate governance. Therefore, the research was extended to explore the role of corporate governance in this matter.

\section{The Role of Corporate Governance}

The regression results for the role of corporate governance (GOV) in each of the six countries using Model (3) estimations are reported in Table 4. For the US firms, this research finds a corporate governance role of 0.3054 on the firms' Tobin's Q score and 0.2851 for their ROA. This role is statistically significant at the 5 percent level. This means the result is in line with the literature addressing the role of corporate governance on better firm performance in the context of the US (e.g. Shleifer and Vishny 1997; Brown and Caylor 2006; Bhagat and Bolton 2008).

Table 3. Estimates of Training and Development Policy and Firm Performance

\begin{tabular}{|c|c|c|c|c|}
\hline & \multicolumn{2}{|c|}{ US } & \multicolumn{2}{|c|}{ Brazil } \\
\hline & Tobin's Q & ROA & Tobin's Q & ROA \\
\hline \multirow{2}{*}{ INTERCEPT } & $-2.1666 * * *$ & $-1.9798^{* * *}$ & $1.6336^{* * *}$ & $1.0161 * * *$ \\
\hline & $(0.0000)$ & $(0.0000)$ & $(0.0000)$ & $(0.0000)$ \\
\hline \multirow{2}{*}{ RLTA } & -0.0465 & -0.0159 & 0.0430 & -0.0170 \\
\hline & $(0.7469)$ & $(0.8884)$ & $(0.4751)$ & $(0.4151)$ \\
\hline \multirow{2}{*}{ ROIS } & $0.0456 * * *$ & $0.0441 * *$ & $0.0409 * * *$ & $0.0354 * *$ \\
\hline & $(0.0008)$ & $(0.0236)$ & $(0.0000)$ & (0.0193) \\
\hline \multirow{2}{*}{ RCES } & $0.9272 * * *$ & $0.9024 * *$ & 0.0036 & 0.0456 \\
\hline & $(0.0015)$ & (0.0199) & $(0.5142)$ & $(0.5155)$ \\
\hline \multirow{2}{*}{ RLEV } & $0.5188^{* * *}$ & $0.5165^{* * *}$ & -0.0246 & -0.0666 \\
\hline & 0.0000 & $(0.0021)$ & $(0.1227)$ & $(0.1682)$ \\
\hline \multirow{2}{*}{ TRAIN } & $0.5527 * * *$ & $0.4278^{* * *}$ & $0.5314^{* *}$ & $0.4919 *$ \\
\hline & $(0.0000)$ & 0.0079 & $(0.0362)$ & $(0.0555)$ \\
\hline \multirow[t]{2}{*}{ Adj R2 } & 0.2811 & 0.2809 & 0.2282 & 0.1893 \\
\hline & \multicolumn{2}{|c|}{ Russia } & \multicolumn{2}{|c|}{ India } \\
\hline \multirow{2}{*}{ INTERCEPT } & $0.9953^{* * *}$ & $0.8785^{* * *}$ & $1.0851 * * *$ & $1.0620 * * *$ \\
\hline & $(0.0000)$ & $(0.0000)$ & $(0.0020)$ & $(0.0000)$ \\
\hline \multirow{2}{*}{ RLTA } & 0.0339 & 0.0363 & -0.0420 & -0.0108 \\
\hline & $(0.4660)$ & $(0.4684)$ & $(0.3901)$ & $(0.4213)$ \\
\hline \multirow{2}{*}{ ROIS } & 0.0121 & 0.0197 & 0.0282 & 0.0127 \\
\hline & $(0.1214)$ & $(0.1263)$ & $(0.1681)$ & $(0.1654)$ \\
\hline \multirow{2}{*}{ RCES } & 0.0053 & 0.0076 & 0.0233 & 0.0395 \\
\hline & $(0.4918)$ & $(0.4938)$ & $(0.1070)$ & $(0.1169)$ \\
\hline \multirow{2}{*}{ RLEV } & -0.0263 & -0.0286 & -0.0443 & 0.0605 \\
\hline & $(0.3272)$ & $(0.2471)$ & $(0.3786)$ & $(0.1481)$ \\
\hline \multirow{2}{*}{ TRAIN } & $0.4497 * * *$ & $0.4250^{* * *}$ & 0.2666 & 0.3040 \\
\hline & $(0.0000)$ & $(0.0042)$ & $(0.1064)$ & $(0.1152)$ \\
\hline Adj R2 & 0.1634 & 0.1658 & 0.1881 & 0.1920 \\
\hline
\end{tabular}


Table 3. Continued

\begin{tabular}{lcccc}
\hline \multirow{2}{*}{ Tobin's Q } & ROA & Tobin's Q & ROA \\
\cline { 2 - 5 } INTERCEPT & \multicolumn{2}{c}{ China } & \multicolumn{2}{c}{ Indonesia } \\
\hline \multirow{2}{*}{ RLTA } & $1.2478^{* * *}$ & $1.0106^{* * *}$ & $1.7356^{* * *}$ & $1.8095^{* * *}$ \\
& $(0.0000)$ & $(0.0000)$ & $(0.0000)$ & $(0.0000)$ \\
ROIS & -0.0480 & -0.0186 & 0.0345 & -0.0287 \\
& $(0.3841)$ & $(0.4135)$ & $(0.4666)$ & $(0.4034)$ \\
RCES & 0.0274 & 0.0143 & $0.0291^{* *}$ & $0.0310^{*}$ \\
& $(0.1224)$ & $(0.1811)$ & $(0.0470)$ & $(0.0846)$ \\
RLEV & 0.0194 & 0.0472 & 0.0058 & 0.0574 \\
& $(0.1221)$ & $(0.1337)$ & $(0.1268)$ & $(0.1248)$ \\
TRAIN & -0.0404 & 0.0682 & -0.0268 & 0.0784 \\
Adj R2 & $(0.1471)$ & $(0.1017)$ & $(0.1429)$ & $(0.1327)$ \\
& 0.3140 & 0.3048 & $0.4026^{* *}$ & $0.4840^{* *}$ \\
& $(0.1261)$ & $(0.1567)$ & $(0.0275)$ & $(0.0146)$ \\
\hline
\end{tabular}

The regression is performed using two different measures of performance: Tobin's $Q$ and ROA. The figure stated are the coefficient values, except numbers in parentheses which are $p$-value. The dependent variable is firm performance. The control variables are relative size (RLTA), relative profitability (ROIS), relative growth (RCES), and relative leverage (RLEV). The main independent variables are Training and Development Policy. The model is as follow:

Value $=\alpha+\beta_{1} L T A_{i, t}+\beta_{2}$ OIS $S_{i, t}+\beta_{3} C E S_{i, t}+\beta_{4} L E V_{i, t}+\beta_{5} \operatorname{TRAIN}_{i, t}+\varepsilon_{i, t}$

Table 4. Estimates of Corporate Governance and Firm Performance

\begin{tabular}{lcccc}
\hline & \multicolumn{2}{c}{ US } & \multicolumn{2}{c}{ Brazil } \\
\cline { 2 - 5 } & Tobin's Q & ROA & Tobin's Q & ROA \\
\hline \multirow{2}{*}{ INTERCEPT } & 0.9081 & $1.9398^{* * *}$ & $0.7723^{* * *}$ & $0.7735^{* * *}$ \\
& $(0.0000)$ & $(0.0000)$ & $(0.0000)$ & $(0.0000)$ \\
LTA & 0.1967 & 0.0273 & 0.1357 & 0.0037 \\
& $(0.2713)$ & $(0.3613)$ & $(0.2223)$ & $(0.2135)$ \\
OIS & $0.0365^{* * *}$ & $0.0437^{* * *}$ & $0.0624^{* * *}$ & $0.0281^{* * *}$ \\
& $(0.0030)$ & $(0.0014)$ & $(0.0032)$ & $(0.0089)$ \\
CES & $0.7701^{* * *}$ & $0.8792^{* * *}$ & $0.5524^{*}$ & $0.4326^{*}$ \\
& $(0.0003)$ & $(0.0020)$ & $(0.0664)$ & $(0.0530)$ \\
LEV & $0.6872^{* * *}$ & $0.5132^{* * *}$ & $0.5296^{* *}$ & $0.4827^{* *}$ \\
& $(0.0001)$ & $(0.0000)$ & $(0.0201)$ & $(0.0102)$ \\
GOV & $0.3054^{* * *}$ & $0.2851^{* * *}$ & $0.4866^{* * *}$ & $0.4400^{* * *}$ \\
Adj R2 & $(0.0000)$ & $(0.0000)$ & $(0.0005)$ & $(0.0000)$ \\
& 0.2737 & 0.2204 & 0.1931 & 0.1845
\end{tabular}


Table 4. Continued

\begin{tabular}{|c|c|c|c|c|}
\hline & Tobin's Q & ROA & Tobin's Q & ROA \\
\hline & \multicolumn{2}{|c|}{ Russia } & \multicolumn{2}{|c|}{ India } \\
\hline INTERCEPT & $\begin{array}{c}0.7509 * * * \\
(0.0000)\end{array}$ & $\begin{array}{c}0.7306^{* * *} \\
(0.0004)\end{array}$ & $\begin{array}{c}0.8702^{* * *} \\
(0.0000)\end{array}$ & $\begin{array}{c}1.0026^{* * *} \\
(0.0000)\end{array}$ \\
\hline LTA & $\begin{array}{c}0.1220 \\
(0.2061)\end{array}$ & $\begin{array}{c}0.0091 \\
(0.2225)\end{array}$ & $\begin{array}{c}0.1493 \\
(0.2555)\end{array}$ & $\begin{array}{c}0.0122 \\
(0.2156)\end{array}$ \\
\hline OIS & $\begin{array}{c}0.0571 * * * \\
(0.0001)\end{array}$ & $\begin{array}{c}0.0326 * * * \\
(0.0008)\end{array}$ & $\begin{array}{c}0.0513 * * * \\
(0.0057)\end{array}$ & $\begin{array}{c}0.0281 * * * \\
(0.0075)\end{array}$ \\
\hline CES & $\begin{array}{c}0.6964 \\
(0.3984)\end{array}$ & $\begin{array}{c}0.4078 \\
(0.2313)\end{array}$ & $\begin{array}{c}0.6391 * * * \\
(0.0035)\end{array}$ & $\begin{array}{l}0.4372^{*} \\
(0.0575)\end{array}$ \\
\hline LEV & $\begin{array}{c}0.1427 \\
(0.1102)\end{array}$ & $\begin{array}{c}0.2050 \\
(0.1940)\end{array}$ & $\begin{array}{c}0.5485^{* * *} \\
(0.0022)\end{array}$ & $\begin{array}{c}0.3068^{* * *} \\
(0.0099)\end{array}$ \\
\hline GOV & $\begin{array}{c}0.4648^{* * *} \\
(0.0010)\end{array}$ & $\begin{array}{c}0.4760 * * * \\
(0.0001)\end{array}$ & $\begin{array}{c}0.3146^{* * *} \\
(0.0068)\end{array}$ & $\begin{array}{c}0.2323 * * * \\
(0.0000)\end{array}$ \\
\hline \multirow[t]{2}{*}{ Adj R2 } & 0.1711 & 0.1691 & 0.1751 & 0.2001 \\
\hline & \multicolumn{2}{|c|}{ China } & \multicolumn{2}{|c|}{ Indonesia } \\
\hline INTERCEPT & $\begin{array}{c}1.0504^{* * *} \\
(0.0000)\end{array}$ & $\begin{array}{c}0.9873 * * * \\
(0.0000)\end{array}$ & $\begin{array}{c}0.8687 * * * \\
(0.0019)\end{array}$ & $\begin{array}{c}1.0855^{* * *} \\
(0.0000)\end{array}$ \\
\hline LTA & $\begin{array}{c}0.1330 \\
(0.2714)\end{array}$ & $\begin{array}{c}0.1149 \\
(0.2907)\end{array}$ & $\begin{array}{c}0.1240 \\
(0.1218)\end{array}$ & $\begin{array}{c}0.0139 \\
(0.1878)\end{array}$ \\
\hline OIS & $\begin{array}{l}0.0466^{*} \\
(0.0552)\end{array}$ & $\begin{array}{c}0.0436 * * \\
(0.0188)\end{array}$ & $\begin{array}{c}0.0502 * * \\
(0.0294)\end{array}$ & $\begin{array}{c}0.0395 * * \\
(0.0338)\end{array}$ \\
\hline CES & $\begin{array}{c}0.6744 * * * \\
(0.0002)\end{array}$ & $\begin{array}{c}0.3750 * * \\
(0.0215)\end{array}$ & $\begin{array}{c}0.5810 * * \\
(0.0189)\end{array}$ & $\begin{array}{c}0.3667 * * \\
(0.0116)\end{array}$ \\
\hline LEV & $\begin{array}{c}0.5638^{* *} \\
(0.0188)\end{array}$ & $\begin{array}{c}0.2919 * * \\
(0.0363)\end{array}$ & $\begin{array}{c}0.4984 * * \\
(0.0208)\end{array}$ & $\begin{array}{c}0.2417 * * \\
(0.0312)\end{array}$ \\
\hline GOV & $\begin{array}{c}0.3057 * * \\
(0.0114)\end{array}$ & $\begin{array}{c}0.4575^{* * *} \\
(0.0000)\end{array}$ & $\begin{array}{c}0.2793 * * \\
(0.0225)\end{array}$ & $\begin{array}{c}0.2463^{* *} \\
(0.0278)\end{array}$ \\
\hline Adj R2 & 0.2227 & 0.2160 & 0.1843 & 0.1837 \\
\hline
\end{tabular}

The regression is performed using two different measures of performance: Tobin's Q and ROA. The figure stated are the coefficient values, except numbers in parentheses which are $p$-value. The dependent variable is firm performance. The control variables are relative size (RLTA), relative profitability (ROIS), relative growth (RCES), and relative leverage (RLEV). The main independent variables are Corporate Governance. The model is as follow Value $=\alpha+\beta_{1} L T A_{i, t}+\beta_{2} O I S_{i, t}+\beta_{3} C E S_{i, t}+\beta_{4} L E V_{i, t}+\beta_{5} G O V_{i, t}+\varepsilon_{i, t}$ 
This research's estimation also finds a significant role by corporate governance in Brazilian firms' performance. Corporate governance has contributed positively, with scores up to 0.4866 and 0.4400 for the Tobin's $Q$ and ROA of the firms in Brazil. This is consistent with the previous works of Klapper and Love (2004), da Silva and Leal (2005), and Estrin and Prevezer (2011) who addressed the important of corporate governance in inducing firm performance in Brazil.

This research continued its investigation into Russia, India, China and Indonesia. Firms in Russia indicated a significant role for corporate governance on firm performance. The estimated coefficient values are 0.4648 for Tobin's Q and 0.4760 for ROA. This is in line with prior research in Russia, such as that undertaken by Black (2001), Klapper and Love (2004), Renders et al. (2010) and Estrin and Prevezer (2011). In the Indian context, it also found a significant contribution by corporate governance on firm performance, where the values are 0.3146 and 0.2323 for Tobin's Q model and ROA model, respectively. Jackling and Johl (2009), and Balasubramanian et al. (2010), and Estrin and Prevezer (2011) arrived at the same conclusion with their research findings, in which they addressed the importance of corporate governance on Indian firms' performance. The positive and significant role of corporate governance in firms' performance is also found in China. The listed firms in China showed a correlation between corporate governance and the firms' performance, where the estimated coefficient values are 0.3057 and 0.4575 for Tobin's Q model and ROA model, respectively. This is consistent with the previous results of $\mathrm{Hu}$ et al. (2010), Sami et al. (2011), Estrin and Prevezer (2011), and
Masulis et al. (2012). Lastly, there is also a positive and significant contribution by corporate governance to firm performance in Indonesia. The magnitude of this influence is also strong, because the estimated coefficient values are 0.2793 for Tobin's $Q$ and 0.2463 for ROA. This is in line with the previous research of Mitton (2002), Klapper and Love (2004), Ramdani and Wittenloostuijn (2010), and Prabowo and Simpson (2011) which concluded that there is a significant relationship between corporate governance and Indonesian firms' performance.

For the control variable's results, this research finds that the estimated coefficient of LTA (size) is positive but not significant to firm performance. The coefficient of OIS (profitability) is positive and significant. The estimated coefficient values are 0.0365 , $0.0624,0.0571,0.0513,0.0466$, and 0.0502 for the Tobin's Q model in the US, Brazil, Russia, India, China, and Indonesia, respectively. This continues with the third control variable, which is CES (growth). This research finds that the growth of the firms contributes significantly only in the US, Brazil, India, China and Indonesia. Growth has no significant role in the performance of Russian firms. Lastly, the estimated coefficient for LEV (leverage) is significant and positive for firms in the US, Brazil, India, China, and Indonesia, but not in Russia. The estimated coefficient values in Tobin's Q model are $0.6872,0.5296,0.5485,0.5638$, and 0.4984 for the US, Brazil, India, China and Indonesia, respectively. Meanwhile, the estimated coefficients of leverage in the ROA model are $0.5132,0.4827,0.2050,0.3068,0.2919$, and 0.2417 for the US, Brazil, India, China and Indonesia, respectively. 


\section{The Moderating Effect of Corporate Governance}

Table 5 reports the estimates of firm performance with TDP, considering the corporate governance of the firms. In Model (1), only the baseline model of firm performance is addressed. Then this research modifies it into Model (2), where TDP is introduced, and Model (3), where corporate governance is introduced. Both models of Tobin's Q and ROA conclude that the main predictors, either TDP or corporate governance, of firm performance in the six-countries are statistically significant. However, a negative sign and/or an insignificant role for the baseline variables are found in certain countries. This intriguing finding makes us want to investigate the interaction between those two main predictors further. This research then hypothesized that there is a moderating role by corporate governance on the relationship between TDP and firm performance. This research believes that a firm with better corporate governance might have different results for its TDP-firm performance association, as compared to a firm with poor corporate governance.

This research proceeded to add an interaction term between TDP and corporate governance to investigate whether the impact of TDP on firm performance differs across different corporate governance levels. This research also controls for the firms' unobservable characteristics, such as differences in their managerial characteristics and corporate cultures by adding a 2 -way firm-period fixed effect and reporting the results of Model (4) in Table 5. Note that the adjusted R2 surmises the model has a good goodness of fit.

The estimates of the baseline variables are the same as the conclusion reported in Table 2. This does not reflect any inconsis- tencies with Model (1), Model (2), Model (3) and Model (4) because with the added interactive terms, this coefficient now represents different conclusions. It is measuring the effect of TDP for the different levels of corporate governance of the firms. The significances of the estimates for TDP $\left(\beta_{5}\right.$ TRAIN $\left._{\mathrm{i}, \mathrm{t}}\right)$ in Model (4) revealed that in the performance of those firms which have a training and development policy. Moreover, the significance of the estimates for corporate governance $\left(\beta_{6} G O V_{i, t}\right)$ in Model (4) also reveals that for the performance of firms which have conducted corporate governance. On the other hand, the interactive terms explain the moderating effect of the model.

After the interactive term is introduced, the baseline variables have a consistent sign and significance with Model (1). The size of the firm is still not significant in associating it with the firms' performance. However, the profitability has regained a significant role in the firms' performance. These remarks are found in all the countries in our study. The growth of firms has also contributed positively and is statistically significant for the firms' performance in 4 countries, which are the US, India, China, and Indonesia. This is totally different to the findings from the estimations of Model (2), where some countries even suffered discounted performance in their growth. Another positive and significant contribution comes from profitability on the firms' performance in all the countries, except Russia.

The results of Table 5 also indicated the same conclusion as the estimations of Model (2) and Model (3), where TDP and corporate governance contributed positively and significantly. However, the significance did not occur in certain countries such as India and China. The estimated coefficient values of TDP $\left(\beta_{5}\right.$ TRAIN $\left._{\mathrm{i}, \mathrm{t}}\right)$ towards Tobins's $\mathrm{Q}$ are 
$0.4223,0.3583,0.4014$ and 0.2299 in the context of the US, Brazil, Russia and Indonesia, respectively. Meanwhile, the estimated coefficient values of TDP $\left(\beta_{5}\right.$ TRAIN $\left._{\mathrm{i}, t}\right)$ towards ROA are 0.4259, 0.3827, 0.3979 and 0.2957 in the context of US, Brazil, Russia and Indonesia, respectively. Furthermore, corporate governance reveals the same conclusion, thus, India and China have been included as their firms have strong and significant associations with corporate governance. The estimated coefficient values of corporate governance 0 are $0.5308,0.3389,0.3391$, $0.2876,0.3526$ and 0.3567 in the context of Tobin's Q for the US, Brazil, Russia, India, China and Indonesia, respectively. Meanwhile, the estimated coefficient values of corporate governance $\left(\beta_{6} \mathrm{GOV}_{\mathrm{it}}\right)$ are 0.5105 , $0.2865,0.2874,0.2927,0.3371$ and 0.2949 in the context of ROA in the US, Brazil, Russia, India, China and Indonesia, respectively.

The results use the interactive term $\left(\beta_{7}\right.$ Train* $\left.\mathrm{GOV}_{\mathrm{it}}\right)$ indicating that different levels of corporate governance may result with the different impacts of TDP on the firms' performance. The research's explanation starts with the US firms, where the interactive term is positive and significant. The estimated coefficient values are 0.2530 and 0.2422 for Tobin's Q and ROA, respectively. Similar to the US context, firms in Brazil also showed a significant association between the interactive terms and the firms' performance, where the estimated coefficient values are 0.2432 and 0.2169 for Tobin's Q and ROA, respectively. This conclusion about the interactive terms and firms' performance is also found in Russia, India, China, and Indonesia, with different magnitudes of the estimated coefficient. In Russia, the association is estimated with coefficient values of 0.2023 (Tobin's Q model) and 0.1970 (ROA model).
Meanwhile, firms in India have the estimated coefficient values of 0.1770 and 0.1980 for Tobin's Q and ROA, respectively. The estimated coefficient values of the interactive terms are 0.2095 (Tobin's Q model) and 0.2158 (ROA model) in China. Lastly, Indonesian firms' performance is significantly induced by the interactive terms with values of 0.1486 (Tobin's Q model) and 0.1400 (ROA model). In short, the interactive terms of TDP and corporate governance have significant influence on both firm performance, Tobin's Q and ROA, in the six countries over a six year period.

Therefore, this research surmised that there is a moderating role of corporate governance on the relationship between TDP and firm performance. The positive sign and increasing $\mathrm{R} 2$ from the interactive terms indicated the moderating role has a good effect on the relationship. The changes of the sign of the baseline variables from negative to positive or from not-significant to significant implied another role for corporate governance in the relationship. This means firms with good corporate governance might manage their TDP well and will have relatively better performance compared to firms with poor corporate governance. Another implication of this research is that good corporate governance not only strengthens the TDP-firm performance relationship, but may also use training and development in a positive manner by not having an inverse relationship between the size of the firm and the firm's performance, or the firm's growth and its performance.

However, this conclusion cannot be found in India and China, which makes this research even more interesting. India and China are two labor-intensive countries which showed that TDP will not have any effect on 
the firms there. Firms in India and China will see no effect; no matter how much these firms spend on their employees' training and development or no matter how intense the investment of the firms in training and development is. Yet, firms with good corporate governance may produce different results. The significance of the sign of the interactive terms indicates that firms in India and China may put the reason for their firms' performance down to their TDP if the firms have good levels of corporate governance.

\section{Robustness Test: Using a Dummy Variable of Corporate Governance}

The results reported in the previous section suggested that corporate governance may influence TDP in obtaining good performance among firms. So far, it has not been explicitly controlled for good levels of corporate governance. To the extent that good or bad corporate governance may also affect the estimated value of Model (4), this research in-

Table 5. Estimates of Training and Development Policy, Corporate Governance, and Firm Performance

\begin{tabular}{|c|c|c|c|c|}
\hline & \multicolumn{2}{|c|}{ US } & \multicolumn{2}{|c|}{ Brazil } \\
\hline & Tobin's Q & ROA & Tobin's Q & ROA \\
\hline \multirow{2}{*}{ INTERCEPT } & $0.9046^{* * *}$ & $0.9050^{* * *}$ & $0.8197^{* * *}$ & $0.8754^{* * *}$ \\
\hline & $(0.0000)$ & $(0.0000)$ & $(0.0009)$ & $(0.0000)$ \\
\hline \multirow{2}{*}{ RLTA } & 0.0465 & 0.0159 & 0.0172 & 0.0167 \\
\hline & $(0.1655)$ & $(0.2128)$ & $(0.2133)$ & $(0.2979)$ \\
\hline \multirow{2}{*}{ ROIS } & $0.0456^{* * *}$ & $0.0441^{* *}$ & $0.0473 * * *$ & $0.0412^{* * *}$ \\
\hline & $(0.0008)$ & $(0.0236)$ & $(0.0021)$ & $(0.0075)$ \\
\hline \multirow{2}{*}{ RCES } & $0.9272^{* * *}$ & $0.9024 * *$ & 0.2456 & 0.2540 \\
\hline & $(0.0015)$ & $(0.0199)$ & $(0.1564)$ & $(0.3312)$ \\
\hline \multirow{2}{*}{ RLEV } & $0.5188^{* * *}$ & $0.5165^{* * *}$ & $0.2767 * *$ & $0.3156^{* * *}$ \\
\hline & $(0.0000)$ & $(0.0021)$ & $(0.0317)$ & $(0.0440)$ \\
\hline \multirow{2}{*}{ TRAIN } & $0.4223^{* * *}$ & $0.4259 * * *$ & $0.3583^{* *}$ & $0.3827 * * *$ \\
\hline & $(0.0000)$ & $(0.0022)$ & $(0.0164)$ & $(0.0015)$ \\
\hline \multirow{2}{*}{ GOV } & $0.5308^{* * *}$ & $0.5105^{* * *}$ & $0.3389 * * *$ & $0.2865^{* * *}$ \\
\hline & $(0.0000)$ & $(0.0004)$ & $(0.0033)$ & $(0.0000)$ \\
\hline \multirow{2}{*}{ TRAIN*GOV } & $0.2530^{* * *}$ & $0.2422^{* * *}$ & $0.2432^{* * *}$ & $0.2169^{* * *}$ \\
\hline & $(0.0002)$ & $(0.0018)$ & $(0.0009)$ & $(0.0022)$ \\
\hline \multirow[t]{2}{*}{ Adj R2 } & 0.3006 & 0.2911 & 0.2459 & 0.2531 \\
\hline & \multicolumn{2}{|c|}{ Russia } & \multicolumn{2}{|c|}{ India } \\
\hline \multirow{2}{*}{ INTERCEPT } & $0.7823^{* * *}$ & $0.7065^{* * *}$ & $0.7054 * * *$ & $0.8468^{* * *}$ \\
\hline & $(0.0000)$ & $(0.0000)$ & $(0.0000)$ & $(0.0000)$ \\
\hline \multirow{2}{*}{ RLTA } & 0.0497 & 0.0378 & 0.0261 & 0.0164 \\
\hline & $(0.7469)$ & $(0.8884)$ & $(0.2140)$ & $(0.3417)$ \\
\hline \multirow{2}{*}{ ROIS } & $0.0369 * * *$ & $0.0440 * *$ & $0.0395^{* *}$ & $0.0483^{* *}$ \\
\hline & $(0.0021)$ & $(0.0119)$ & $(0.0125)$ & $(0.0137)$ \\
\hline
\end{tabular}


Table 5. Continued

\begin{tabular}{|c|c|c|c|c|}
\hline & \multicolumn{2}{|c|}{ Russia } & \multicolumn{2}{|c|}{ India } \\
\hline & Tobin's Q & ROA & Tobin's Q & ROA \\
\hline \multirow{2}{*}{ RCES } & 0.2615 & 0.2627 & $0.7430 * *$ & $0.5425^{* * *}$ \\
\hline & $(0.1653)$ & $(0.3517)$ & $(0.0265)$ & $(0.0065)$ \\
\hline \multirow{2}{*}{ RLEV } & 0.1772 & 0.1230 & $0.4368 * * *$ & $0.3474 * * *$ \\
\hline & $(0.1073)$ & $(0.1363)$ & $(0.0017)$ & $(0.0019)$ \\
\hline \multirow{2}{*}{ TRAIN } & $0.4014^{* *}$ & $0.3979 * *$ & 0.1779 & 0.1919 \\
\hline & $(0.0101)$ & $(0.0360)$ & $(0.1437)$ & $(0.1012)$ \\
\hline \multirow{2}{*}{$\mathrm{GOV}$} & $0.3391 * * *$ & $0.2874 * * *$ & $0.2876^{* * *}$ & $0.2927 * * *$ \\
\hline & $(0.0056)$ & $(0.0000)$ & $(0.0001)$ & $(0.0060)$ \\
\hline \multirow{2}{*}{ TRAIN*GOV } & $0.2023 * * *$ & $0.1970^{* * *}$ & $0.1770 * *$ & $0.1980^{* *}$ \\
\hline & $(0.0006)$ & $(0.0037)$ & $(0.0144)$ & $(0.0145)$ \\
\hline \multirow[t]{2}{*}{ Adj R2 } & 0.2154 & 0.2166 & 0.2353 & 0.2093 \\
\hline & \multicolumn{2}{|c|}{ China } & \multicolumn{2}{|c|}{ Indonesia } \\
\hline \multirow{2}{*}{ INTERCEPT } & $0.8197 * * *$ & $0.7629 * * *$ & $0.8739 * * *$ & $0.7373 * * *$ \\
\hline & $(0.0000)$ & $(0.0000)$ & $(0.0000)$ & $(0.0000)$ \\
\hline \multirow{2}{*}{ RLTA } & 0.0375 & 0.0312 & 0.0266 & 0.0184 \\
\hline & $(0.2240)$ & $(0.3383)$ & $(0.3275)$ & $(0.2128)$ \\
\hline \multirow{2}{*}{ ROIS } & $0.0383^{* * *}$ & $0.0463^{* * *}$ & $0.0448^{* * *}$ & $0.0398 * * *$ \\
\hline & $(0.0028)$ & $(0.0030)$ & $(0.0032)$ & $(0.0078)$ \\
\hline \multirow{2}{*}{ RCES } & $0.7458^{* *}$ & $0.6440^{* * *}$ & $0.7549 * *$ & $0.5743 * * *$ \\
\hline & $(0.0279)$ & $(0.0177)$ & $(0.0292)$ & $(0.0069)$ \\
\hline \multirow{2}{*}{ RLEV } & $0.4700^{* * *}$ & $0.3418^{*}$ & $0.4166^{* * *}$ & $0.3085^{*}$ \\
\hline & $(0.0060)$ & $(0.0619)$ & $(0.0060)$ & $(0.0627)$ \\
\hline \multirow{2}{*}{ TRAIN } & 0.1347 & 0.1506 & $0.2299 * *$ & $0.2957^{*}$ \\
\hline & $(0.1517)$ & $(0.2127)$ & $(0.0148)$ & $(0.0746)$ \\
\hline \multirow{2}{*}{ GOV } & $0.3526^{* * *}$ & $0.3371 * *$ & $0.3567 * * *$ & $0.2949 * *$ \\
\hline & $(0.0000)$ & $(0.0351)$ & $(0.0000)$ & $(0.0156)$ \\
\hline \multirow{2}{*}{ TRAIN*GOV } & $0.2095^{* * *}$ & $0.2158^{* * *}$ & $0.1486^{* * *}$ & $0.1400^{* * *}$ \\
\hline & $(0.0081)$ & $(0.0075)$ & $(0.0052)$ & $(0.0057)$ \\
\hline Adj R2 & 0.2496 & 0.2356 & 0.2235 & 0.2065 \\
\hline
\end{tabular}

The regression is performed using two different measures of performance: Tobin's $Q$ and ROA. The figure stated are the coefficient values, except numbers in parentheses which are $p$-value. The dependent variable is firm performance. The control variables are relative size (RLTA), relative profitability (ROIS), relative growth (RCES), and relative leverage (RLEV). The main independent variables are Training and Development Policy (TDP), and Corporate Governance. The innovation in this research is the interactive terms between TDP and corporate governance as this research aims to investigate the moderating role of corporate governance on the relationship between TDP and Firm performance. The model is as follow: Value $=\alpha+\beta_{1} L T A_{i, t}+\beta_{2} O I S_{i, t}+\beta_{3} C E S_{i, t}+\beta_{4} L E V_{i, t}+\beta_{5} \operatorname{Train}_{, t}+\beta_{6} G O V_{i, t}+\beta_{7} \operatorname{Train}^{*} G O V_{i, t}+\varepsilon_{i, t}$ 
vestigates further by establishing a dummy variable for the level of corporate governance. Table 6 depicts different estimates of Model (4) where the corporate governance index is modified into a binary dummy variable.

The dummy variable is created by using the following procedure. First, the mean is taken after sorting out the governance index from the highest to the lowest in each year, according to each country. Then, those firms with a corporate governance index higher than the average value are given 1 and 0 otherwise. The data set of the corporate governance index is replaced by this new dummy variable data. After that, it proceeded by re-employing Model (4).

The results showed the indifferent conclusions except for the control variables. Profitability and leverage contributed positively and were statistically significant to the firms' performance in all countries, including Brazil and Russia. Meanwhile, India, China, and Indonesia lost the growth effect on the firms' performance. Size still does not have any significant effect on the firms' performance.

The interactive terms for new corporate governance arrived at the same conclusion; there is a moderating role by corporate governance on the relationship between TDP and the firms' performance, as reported in Table 6.This study also found that within each country, the role of corporate governance differed. Based on the estimated coefficient, the moderating role of corporate governance is significantly higher for US firms. Interestingly, there are no consistent results between Tobin's Q and ROA when this research used these new interactive terms. This research believes this is due to the variance of the indexation of the corporate governance's level, or in other words, a statistical problem. Another issue that may arise in this research is that there are no exact corporate governance items that may enhance the TDP-firm performance link. For instance, board structure and compenzation policy may have different impacts on the relationship. The researchers leave this issue for future research.

Table 6. Robustness Test by Using Binary Variable of Corporate Governance

\begin{tabular}{lcccc}
\hline & \multicolumn{2}{c}{ US } & \multicolumn{2}{c}{ Brazil } \\
\cline { 2 - 5 } & Tobin's Q & ROA & Tobin's Q & ROA \\
\hline \multirow{2}{*}{ INTERCEPT } & $2.1219^{* * *}$ & $2.1487^{* * *}$ & $1.9839^{* * *}$ & $2.1027^{* * *}$ \\
\multirow{2}{*}{ RLTA } & $(0.0000)$ & $(0.0000)$ & $(0.0000)$ & $(0.0000)$ \\
& 0.2956 & 0.2390 & 0.2124 & 0.1956 \\
ROIS & $(0.4690)$ & $(0.5884)$ & $(0.5851)$ & $(0.6549)$ \\
& $0.1036^{* * *}$ & $0.0895^{* *}$ & $0.0887^{* *}$ & $0.0413^{* * *}$ \\
RCES & $(0.0008)$ & $(0.0236)$ & $(0.0410)$ & $(0.0080)$ \\
& $0.7017^{* * *}$ & $0.6913^{* *}$ & 0.4683 & 0.2784 \\
RLEV & $(0.0015)$ & $(0.0199)$ & $(0.1906)$ & $(0.1704)$ \\
& $0.5148^{* * *}$ & $0.3879^{* * *}$ & $0.4276^{* *}$ & $0.2852^{* *}$ \\
TRAIN & $(0.0000)$ & $(0.0021)$ & $(0.0462)$ & $(0.0401)$ \\
& $0.5563^{* * *}$ & $0.5628^{* *}$ & $0.1868^{* *}$ & $0.1967^{*}$
\end{tabular}


Table 6. Continued

\begin{tabular}{|c|c|c|c|c|}
\hline & \multicolumn{2}{|c|}{ US } & \multicolumn{2}{|c|}{ Brazil } \\
\hline & Tobin's Q & ROA & Tobin's Q & ROA \\
\hline \multirow{2}{*}{ GOV } & $0.0558 * * *$ & $0.0627 * * *$ & $0.0120 * * *$ & $0.0175^{* * *}$ \\
\hline & $(0.0000)$ & $(0.0001)$ & $(0.0005)$ & $(0.0000)$ \\
\hline \multirow{2}{*}{ TRAIN*GOV } & $0.0734 * * *$ & $0.0403 * * *$ & $0.0474 * * *$ & $0.0478^{* * *}$ \\
\hline & $(0.0000)$ & $(0.0002)$ & $(0.0002)$ & $(0.0000)$ \\
\hline \multirow[t]{2}{*}{ Adj R2 } & 0.1530 & 0.1244 & 0.0774 & 0.0922 \\
\hline & \multicolumn{2}{|c|}{ Russia } & \multicolumn{2}{|c|}{ India } \\
\hline \multirow{2}{*}{ INTERCEPT } & $2.0397 * * *$ & $1.8928^{* * *}$ & $2.0047^{* * *}$ & $1.7772^{* * * *}$ \\
\hline & $(0.0000)$ & $(0.0020)$ & $(0.0000)$ & $(0.0000)$ \\
\hline \multirow{2}{*}{ RLTA } & 0.2088 & 0.2083 & 0.1864 & 0.1808 \\
\hline & $(0.7084)$ & $(0.7126)$ & $(0.5704)$ & $(0.6656)$ \\
\hline \multirow{2}{*}{ ROIS } & $0.0175^{*}$ & $0.0511 * *$ & $0.0704^{*}$ & $0.0701 * * *$ \\
\hline & $(0.0585)$ & $(0.0120)$ & $(0.0635)$ & $(0.0078)$ \\
\hline \multirow{2}{*}{ RCES } & 0.1811 & 0.3107 & 0.5906 & 0.3175 \\
\hline & $(0.1813)$ & $(0.1676)$ & $(0.1641)$ & $(0.1116)$ \\
\hline \multirow{2}{*}{ RLEV } & $0.4804^{*}$ & $0.3329 *$ & $0.3966^{* *}$ & $0.2868^{* * *}$ \\
\hline & $(0.0733)$ & $(0.0882)$ & $(0.0468)$ & $(0.0031)$ \\
\hline \multirow{2}{*}{ TRAIN } & $0.2364 * *$ & $0.2616 * *$ & 0.1751 & 0.1824 \\
\hline & $(0.0471)$ & $(0.0485)$ & $(0.1061)$ & $(0.1452)$ \\
\hline \multirow{2}{*}{ GOV } & $0.0196^{* * *}$ & $0.0331 * * *$ & $0.0473 * * *$ & $0.0496 * * *$ \\
\hline & $(0.0000)$ & $(0.0034)$ & $(0.0044)$ & $(0.0000)$ \\
\hline \multirow{2}{*}{ TRAIN*GOV } & $0.0281 * * *$ & $0.0187 * * *$ & $0.0392 * *$ & $0.0214^{* * *}$ \\
\hline & $(0.0071)$ & $(0.0000)$ & $(0.0169)$ & $(0.0000)$ \\
\hline \multirow[t]{2}{*}{ Adj R2 } & 0.0812 & 0.0655 & 0.0945 & 0.1009 \\
\hline & \multicolumn{2}{|c|}{ China } & \multicolumn{2}{|c|}{ Indonesia } \\
\hline \multirow{2}{*}{ INTERCEPT } & $1.8752 * * *$ & $1.7968^{* * *}$ & $1.8948^{* * *}$ & $1.9997 * * *$ \\
\hline & $(0.0000)$ & $(0.0000)$ & $(0.0000)$ & $(0.0000)$ \\
\hline \multirow{2}{*}{ RLTA } & 0.2228 & 0.2035 & 0.1706 & 0.2344 \\
\hline & $(0.5711)$ & $(0.6979)$ & $(0.5374)$ & $(0.5899)$ \\
\hline \multirow{2}{*}{ ROIS } & $0.0931^{*}$ & $0.0390^{* *}$ & $0.0920 * *$ & $0.0193^{* *}$ \\
\hline & $(0.0684)$ & $(0.0366)$ & $(0.0125)$ & $(0.0109)$ \\
\hline \multirow{2}{*}{ RCES } & 0.3211 & 0.2754 & 0.3462 & 0.3466 \\
\hline & $(0.1476)$ & $(0.1106)$ & $(0.1629)$ & $(0.1082)$ \\
\hline \multirow{2}{*}{ RLEV } & $0.3949 * *$ & $0.3311^{* * *}$ & $0.2687^{* *}$ & $0.2589 * *$ \\
\hline & $(0.0478)$ & $(0.0044)$ & $(0.0329)$ & $(0.0104)$ \\
\hline
\end{tabular}


Table 6. Continued

\begin{tabular}{|c|c|c|c|c|}
\hline & Tobin's Q & ROA & Tobin's Q & ROA \\
\hline & \multicolumn{2}{|c|}{ China } & \multicolumn{2}{|c|}{ Indonesia } \\
\hline \multirow{2}{*}{ TRAIN } & 0.1262 & 0.1488 & $0.2330^{* *}$ & $0.1062 * *$ \\
\hline & $(0.1613)$ & $(0.1655)$ & $(0.0408)$ & $(0.0420)$ \\
\hline \multirow{2}{*}{ GOV } & $0.0351 * * *$ & $0.0100^{* * *}$ & $0.0710^{* * *}$ & $0.0123 * * *$ \\
\hline & $(0.0000)$ & $(0.0060)$ & $(0.0000)$ & $(0.0001)$ \\
\hline \multirow{2}{*}{ TRAIN*GOV } & $0.0322 * * *$ & $0.0292 * * *$ & $0.0308^{* *}$ & $0.0344 * * *$ \\
\hline & $(0.0085)$ & $(0.0000)$ & $(0.0351)$ & $(0.0000)$ \\
\hline Adj R2 & 0.2446 & 0.1101 & 0.0824 & 0.0963 \\
\hline
\end{tabular}

The regression is performed using two different measures of performance: Tobin's Q and ROA. The figure stated are the coefficient values, except numbers in parentheses which are $p$-value. The dependent variable is firm performance. The control variables are relative size (RLTA), relative profitability (ROIS), relative growth (RCES), and relative leverage (RLEV). The main independent variables are Training and Development Policy (TDP), and Corporate Governance. The innovation in this research is the interactive terms between TDP and corporate governance. This is robustness check of the moderating role by creating a dummy variable of corporate governance. The model is as follow:

Value $=\alpha+\beta_{1}$ LTA $_{t, t}+\beta_{2}$ OIS $S_{i, t}+\beta_{3}$ CES $_{i, t}+\beta_{4} L E V_{i, t}+\beta_{5}$ Train $_{t, t}+\beta_{6}$ GOV $_{i, t}+\beta_{7}$ Train $^{*} G O V_{i, t}+\varepsilon_{i, t}$

\section{Results Discussion}

This study revealed that a Training and Development Policy (TDP) plays an important role in firms' performance, which is consistent with previous empirical papers such as those by Storey (2002), Storey (2004), and Kwon and Rupp (2013). Even so, the role of TDP on firm performance is not always true. Particularly, this research discovered that the significant effect of TDP on firm performance is very weak in India and China. Moreover, the literature showed that a firm with good corporate governance may have a better policy-performance association (e.g. Shleifer and Vishny 1997; Kwon and Rupp 2013). Hence, this research continued to investigate further by exploring the mediating role of corporate governance on the TDP and firm performance.

This research followed up on this unjustified explanation by using a corporate governance index. This index consisted of four important dimensions namely, board structure, board function, compenzation policy, and shareholder rights. Of course, using this index does not explain which dimension, or dimensions, have an effect on the relationship between TDP and firm performance. But at least, this is the best data available and also the best method to reduce the excessive variance, which is a result of having too many predictors, especially the multicollinearity, heteroscedasticity, and autocorrelation issues.

The results demonstrated interesting findings, where corporate governance might enhance the relationship between TDP and firm performance. The negative signs of the variables in the TDP model are also changing to positive, and the magnitude of the estimated coefficient is bigger. India and China, where TDP does not have an effect on firm performance, showed an inverse relationship. This implied that corporate governance relatively fixes the firms' performance through imposing TDP. 
In other words, successful training and development relies on the corporate governance of the firms. Firms without good corporate governance ended up with low growth and probably also grow smaller. The substantial outlay that organizations spend each year on formal training and development programs is made with the expectation that their training investments will lead to improvements in their organizational performance, but this is hugely based on the corporate governance performance of the firm. This is consistent with studies by Bunch (2007), and Deng et al. (2012), which addressed the success rate of training and development and found it depends on the governance of the firm. Using Shleifer and Vishny (1997) to postulate the conclusion, TDP, which is an investment for better firm performance, will be successful if the firm has good corporate governance. A better level of corporate governance might prohibit the managers from personally profiting from business operations such as training and development. This implied that firms with good levels of corporate governance may perform relatively better from their training and development programmes as compared to those firms without good levels of corporate governance. Moreover, this research also showed that without a good level of corporate governance, a firm might suffer from the incurred cost of its training and development. Besides that, training and development policies without good corporate governance may reduce the size and growth of firms, as can be illustrated from cases in India and China.

\section{Research Implications for Companies}

Does a Training and Development Policy (TDP) affect firm performance? Industry and policy makers may benefit in their policymaking processes from the answer.
Often, training and development is treated as cost center, hence, companies will ignore it. The thought that trained staff will leave the company after achieving better capabilities pushes companies to have bad policies regarding this matter. Yet, the results of this study show differently. They show that TDP is important for firm performance, meaning that TDP is a good investment for a company. Second, to ensure the return of TDP by improved performance, a company has to have good corporate governance.

Hence, the findings from this research have two main implications for companies. First, it is empirically proven that employing TDP in an organization is good for the performance. This implies companies should invest in their human resources, especially training and development, to induce improved performance. Second, there is a moderating role by corporate governance on the TDPperformance link, indicating the need for good corporate governance to ensure the return from TDP. This implies that companies should have better monitoring or governance to make sure their TDP is working. In other words, corporate governance is essential for companies to obtain a good return from their TDP outlays.

\section{Conclusions}

This research aims to investigate the role of governance on the relationship between TDP and firm performance. This research constructed a panel data set with a large range of firms from countries such as Brazil, Russia, India, China, Indonesia, and the US over the period from 2007 to 2013, and explored how much of the performance of TDP appears to arise from the structure of their corporate governance. The baseline model consists of profitability (operating income to 
sales), growth (capital expenditure to sales), leverage (debt to equity), and size (natural logarithm of the total assets). Firm performance is measured more comprehensively than in prior studies in the area, where the return on assets and Tobin's Q are used. The TDP is a dummy variable which is 1 if the firm imposes TDP, and 0 otherwise. The corporate governance is measured by a well-established index called the corporate governance performance index. This index is more robust than the exclusive ownership variables, because it also includes board structure, board function, compenzation policy, and shareholder rights. Another reason for using this index is to avoid the statistical issues if there are too many independent variables, such as type 1 or type 2 errors. As a robustness test, corporate governance's performance is further clustered into the dummy variable of good corporate governance and poor corporate governance, and then re-run again in the model by using this governance dummy variable.

The results documented three interesting findings. Once this research accounted for the impact of corporate governance on firm value, the researchers found a positive and significant relationship between corporate governance and firm performance. This means a company with good corporate governance tends to have good performance. This research continued by introducing only TDP into the baseline mode. The researchers found that TDP contributed positively and significantly to the firm performance, confirming the postulate of the link between TDP and performance. For example, firms imposing TDP may have increased efficiency at work, leading to better productivity by the firms and better performance as compared to firms without TDP. Interestingly, the baseline model (profitability, growth, size, and leverage) lost its contribution to performance when this research introduced TDP into the model. This indicated that imposing TDP in a firm is more important than the financial factor in relation to improving the firm's performance. Lastly, this research tested whether corporate governance plays an important role in the relationship between TDP and firm performance. Using the corporate governance index, this research found that there is a significant effect by corporate governance on the relationship between TDP and firm performance. This research then continued to the robustness test by using the governance dummy variable and found the same results. This means that TDP will influence a firm's performance if it has good corporate governance. In a nutshell, this research concluded that corporate governance plays an important role in the relationship between TDP and firm performance. This implies that firms with TDP and good corporate governance will outperform those firms with TDP but poor corporate governance and firms without TDP.

This research may sum up two theories: the knowledge transfer theory and human capital theory. This research explored the use of the knowledge transfer theory in explaining the relationship between TDP and firm performance. According to this theory, when trained employees transfer or share their knowledge in their organization's operations, the organization will become more efficient and effective which means they will have human capital, which is important for ensuring the success of the firm's performance. This research's findings confirmed it by showing the positive and significant effects of TDP on firm performance. Additionally, this research enriches the human capital theory, where it showed how increases in their human capital enabled firms to operate better. 
However, the findings need to be validated by further research, conducted in other developed markets or emerging markets, in order to verify some facts about certain common characteristics embedded in the developed markets or in the emerging markets. The focus of this study has been to examine the role of corporate governance on the relationship of TDP and firm performance. Based on certain limitation, a few extensions can be further built upon this analysis. Firstly, more details of the training and development investment by the firms may give different insights. Secondly, corporate governance such as the board's structure, shareholder rights, firm's identity, or even compenzation policy can give more insights into the TDP-firm performance association. Lastly, this study is limited to a full dimension of corporate governance, where each type of governance may have different effects on the relationship between TDP and performance. Future research may develop a corporate governance dimension based on certain characteristics, and test it to see what type of governance has a significant effect on the links between TDP and performance. Additionally, some of the internal corporate governance's attributes, such as the roles of families and governmentlinked companies' directors can be another interesting extension of this study.

\section{References}

Ahmad, N. M. N. N., A. Nawawi, and A. S. A. P. Salin. 2016. The relationship between human capital and Director's Remuneration of Malaysian Public Listed Companies. International Journal of Business and Society 17 (2): 347.

Alliger, G. M., S. I. Tannenbaum, W. Bennett, H. Traver, and A. Shortland. 1997. A meta-analysis on the relations among training criteria. Personnel Psychology 50: 341"358.

Ambrosini, V., C. Bowman, and N. Collier. 2009. Dynamic capabilities: An exploration of how firms renew their resource base. British Journal of Management 20: 9-24.

Armstrong, M., and S. Taylor. 2014. Armstrong's Handbook of Human Resource Management Practice. Kogan Page Publishers.

Balasubramanian, N., B. S. Black, and V. Khanna. 2010. The relation between firm-level corporate governance and market value: A case study of India. Emerging Markets Review 11 (4): 319-340.

Baltagi, B. 2008. Econometric Analysis of Panel Data. John Wiley \& Sons.

Bhagat, S., and B. Bolton. 2008. Corporate governance and firm performance. Journal of Corporate Finance 14 (3): 257-273.

Black, B. 2001. The corporate governance behavior and market value of Russian firms. Emerging Markets Review 2 (2): 89-108.

Black, B. S., H. Jang, and W. Kim. 2006. Does corporate governance predict firms' market values? Evidence from Korea. Journal of Law, Economics, and Organization 22 (2): 366-413.

Boudreau, J. W. 2006. Talentship and HR measurement and analysis: From ROI to strategic organizational change. People and Strategy 29 (1): 25.

Bowers, A. J. 2017. Quantitative research methods training in education leadership and administration preparation programs as disciplined inquiry for building school improvement capacity. Journal of Research on Leadership Education 12 (1): 72-96. 
Brown, L. D., and M. L. Caylor. 2004. Corporate governance and firm performance. Corporate Governance: An International Review 12 (4): 436-441.

Bunch, K. J. 2007. Training failure as a consequence of organizational culture. Human Resource Development Review 6 (2): 142-163.

Caudron, S. 2002. Just say no to training fads. Training and Development 56 (6): $40 " 43$.

da Silva, A. L. C., and R. P. C. Leal. 2005. Corporate governance index, firm valuation and performance in Brazil. Brazilian Review of Finance 3 (1): 1.

Deardorff, A., and S. Djankov. 2000. Knowledge transfer under subcontracting: Evidence from Czech firms. World Development 28 (10): 1837-1847.

Deng, Z., P. S. Hofman, and A. Newman. 2012. Ownership concentration and product innovation in Chinese private SMEs. Asia Pacific Journal Management 30: 717-734

de Kok, J., L. M. Uhlaner, and R. Thurik. 2003. Human resource management with small firms; facts and explanations. ERIM Report Research Series Research in Management. (https://papers.ssrn.com/sol3/ papers.cfm?abstract_id $=411655)$.

Dolezalek, H. (2005). 2005 Industry report. Training, 42(12), 14"28

Dukhan, N. R., N. Mohamad, and A. B. Ali. 2017. Factors affecting on the employees' performance study on the Al-Zawiya University of Libya. International Review of Management and Business Research 6 (1): 145.

Estrin, S., and M. Prevezer. 2011. The role of informal institutions in corporate governance: Brazil, Russia, India, and China compared. Asia Pacific journal of management 28 (1); 41-67.

Fauver, L., J. F. Houston, and A. Naranjo. 2004. Cross-country evidence on the value of corporate industrial and international diversification. Journal of Corporate Finance 10 (5): 729-752.

Ganotakis, P. 2012. Founders' human capital and the performance of UK new technology based firms. Small Business Economics 39 (2): 495-515.

Hajidimitriou, Y. A., N. S. Sklavounos, and K. P. Rotsios. 2012. The impact of trust on knowledge transfer in international business systems. Scientific Bulletin-Economic Sciences 11 (2): 39-49.

Hsiao, Y. C., C. J. Chen, B. W. Lin, and C. I. Kuo. 2017. Resource alignment, organizational distance, and knowledge transfer performance: the contingency role of alliance form. The Journal of Technology Transfer 42 (3): 635-653.

Hsu, L. C., and C. H. Wang. 2010. Clarifying the effect of intellectual capital on performance. The mediating role of dynamic capability. British Journal of Management (DOI: 10.1111/j.14678551.2010.00718.x).

Hu, H. W., O. K. Tam, and M. G. S. Tan. 2010. Internal governance mechanisms and firm performance in China. Asia Pacific Journal of Management 27 (4): 727-749.

Jackling, B., and S. Johl. 2009. Board structure and firm performance: Evidence from India's top companies. Corporate Governance: An International Review 17 (4): 492-509.

Jardon, C. M., and A. Dasilva. 2017. Intellectual capital and environmental concern in subsistence small businesses. Management of Environmental Quality: An International Journal 28 (2): 214-230.

Jardon, C. M., and M. S. Martos. 2009. Intellectual capital and performance in wood industries of Argentina. Journal of Intellectual Capital 10 (4): 600-616.

Kamukama, N., and T. Sulait. 2017. Intellectual capital and competitive advantage in Uganda's microfinance 
industry. African Journal of Economic and Management Studies 8 (4): 498-514.

Ketchen Jr, D. J., T. R. Crook, S. Y. Todd, J. G. Combs, and D. J. Woehr. 2017. Managing human capital. The Oxford Handbook of Strategy Implementation: 283.

Khan, R. A. G., F. A. Khan, and M. A. Khan. 2011. Impact of training and development on organizational performance. Global Journal of Management and Business Research 11 (7).

Klapper, L. F., and I. Love. 2004. Corporate governance, investor protection, and performance in emerging markets. Journal of Corporate Finance 10 (5): 703-728.

Kraiger, K. 2003. Perspectives on training and development. Handbook of Psychology.

Kraiger, K., D. McLinden, and W. J. Casper. 2004. Collaborative planning for training impact. Human Resource Management 43: 337"351.

Kwon, K., and E. Rupp. 2013. High performer turnover and firm performance: The moderating role of human capital investment and firm reputation. Journal of Organizational Behavior 34 (1): 129-150.

Lee, K. T., C. W. Hooy, and G. K. Hooy. 2012. The value impact of international and industrial diversifications on public listed firms in Malaysia. Emerging Markets Review 13 (3): 366-380.

Lepak, D. P., and S. A. Snell. 1999. The human resource architecture: Toward a theory of human capital allocation and development. Academy of management review 24 (1): 31-48.

Lepak, D., and M. Gowan. 2010. Human Resource Management. Managing Employees for Competitive Advantage. New Jersey NJ: Pearson-Prentice Hall.

Madarisa, F., M. Noer, Asmawi, and Jafrinur. 2017. Collaborative training to improve beef cattle farmers' technical competency in West Pasaman District. International Journal of Agricultural Sciences 1 (1): $39-47$.

Marimuthu, M., L. Arokiasamy, and M. Ismail. 2009. Human capital development and its impact on firm performance: Evidence from developmental economics. Journal of International Social Research 2 (8).

Masulis, R. W., C. Wang, and F. Xie. 2012. Globalizing the boardroom-The effects of foreign directors on corporate governance and firm performance. Journal of Accounting and Economics 53 (3): 527-554.

Mitton, T. 2002. A cross-firm analysis of the impact of corporate governance on the East Asian financial crisis. Journal of Financial Economics 64 (2): 215-241.

Narwal, K. P., and N. Yadav. 2017. Evaluating intellectual capital and its impact on financial performance: empirical evidence from Indian electricity, mining and asset financing service sectors. International Journal of Learning and Intellectual Capital 14 (4): 319-337.

Nguyen, T. N., Q. Truong, and D. Buyens. 2011. Training and firm performance in economies in transition: a comparison between Vietnam and China. Asia Pacific Business Review 17 (01): 103-119.

Parham, S., and G. W. Heling. 2015. The relationship between human capital efficiency and financial performance of Dutch production companies. Research Journal of Finance and Accounting 6 (8), 188201.

Petersen. 2009. Estimating standard errors in finance panel data sets: Comparing approaches. Review of Financial Studies 22 (1): 435-480.

Prabowo, M., and J. Simpson. 2011. Independent directors and firm performance in family controlled firms: evidence from Indonesia. Asian Pacific Economic Literature 25 (1): 121-132. 
Ramdani, D., and A. V. Witteloostuijn. 2010. The impact of board independence and CEO duality on firm performance: A quantile regression analysis for Indonesia, Malaysia, South Korea and Thailand. British Journal of Management 21 (3): 607-627.

Renders, A., A. Gaeremynck, and P. Sercu. 2010. Corporate governance ratings and company performance: A cross european Study. Corporate Governance: An International Review 18 (2): 87-106.

Salas, E., and J. A. Cannon-Bowers. 2001. The science of training: A decade of progress. Annual Review of Psychology 52 (1): 471-499.

Sami, H., J. Wang, and H. Zhou. 2011. Corporate governance and operating performance of Chinese listed firms. Journal of International Accounting, Auditing and Taxation 20 (2): 106-114.

Shleifer, A., and R. W. Vishny. 1997. A survey of corporate governance. The Journal of Finance 52 (2): 737783.

Storey, D. J. 2002. Education, training and development policies and practices in medium-sized companies in the UK: do they really influence firm performance? Omega 30 (4): 249-264.

Storey, D. J. 2004. Exploring the link, among small firms, between management training and firm performance: a comparison between the UK and other OECD countries. The International Journal of Human Resource Management 15 (1): 112-130.

Subramaniam, M., and M. A. Youndt. 2005. The influence on intellectual capital on the types of innovative capabilities. Academy of Management Journal 48 (3): 450-463.

Tharenou, P., A. M. Saks, and C. Moore. 2007. A review and critique of research training and organizational-level outcomes. Human Resource Management Review 17: 251-273.

Tsai, W. 2001. Knowledge transfer in intraorganizational networks: Effects of network position and absorptive capacity on business unit innovation and performance. Academy of Management Journal 44 (5): 996-1004.

Tsaur, S. H., and Y. C. Lin. 2004. Promoting service quality in tourist hotels: the role of HRM practices and service behavior. Tourism Management 25 (4): 471-481.

Vomberg, A., C. Homburg, and T. Bornemann. 2015. Talented people and strong brands: The contribution of human capital and brand equity to firm value. Strategic Management Journal 36 (13): 21222131.

Westerfield, R., W., A. A. Ross, and J. Jaffe. 2005. Corporate Finance ( $7^{\text {th }}$ ed.). New York, NY: McGraw-Hill International Edition

Wright, P. C., and G. D. Geroy. 2001. Changing the mindset: The training myth and the need for worldclass performance. International Journal of Human Resource Management 12 (4): 586-600.

Zahra, S., H. J. Sapienza, and P, Davidsson. 2006. Entrepreneurship and dynamic capabilities: a review, model and research agenda. Journal of Management Studies 43 (4): 917-955. 
